\title{
Substrate use in horses during exercise - the 'fasted' compared to the postprandial state
}

\author{
Substraatgebruik bij paarden tijdens inspanning - een vergelijking tussen \\ de 'gevaste' en postprandiale status
}

\author{
${ }^{1} \mathrm{~J}$. Robyn, ${ }^{1} \mathrm{~L}$. Plancke, ${ }^{1,2}$ B. Boshuizen, ${ }^{1} \mathrm{C}$. de Meeûs, ${ }^{2} \mathrm{M}$. de Bruijn, ${ }^{1} \mathrm{C}$. Delesalle \\ ${ }^{1}$ Department of Comparative Physiology and Biochemistry, Faculty of Veterinary Medicine, \\ Ghent University, Salisburylaan 133, 9820 Merelbeke, Belgium \\ ${ }^{2}$ Sportpaardenkliniek Wolvega, Stellingenweg 10, 8474 EA Oldeholtpade, the Netherlands
}

Catherine.Delesalle@UGent.be

\begin{abstract}
$\Lambda_{\text {bstract }}$
Training in the fasted state has beneficial effects on performance in the human athlete. In the horse, training in the fasted state is associated with an increased mobilization of non-esterified fatty acids (NEFA) as an energy source. This is in contrast with postprandial (grain-fed) training, during which lipolysis is suppressed. A higher NEFA availability is thought to reduce muscle glycogen depletion and muscle acidification. This could aid in delaying muscle fatigue. The equine gastrointestinal tract and roughage rich diet do not allow a real 'fasted' state. Luckily, roughage does not induce high plasma insulin peaks, and therefore does not have the same negative effects as grain feeding. Furthermore, the roughage-containing hindgut serves as a fluid and electrolyte buffer and continuously provides the liver with propionic acid, a precursor used in gluconeogenesis. In horses, unlike in human athletes, there is still a lot to discover when it comes to optimal pre-exercise feeding management throughout competition and training. However, whatever approach is chosen, high quality roughage needs to be the key ingredient of the equine diet. In sport horses with high energy demands, feeding good quality roughage may be combined with fibre rich concentrates, pelleted roughages sources or vegetal oil instead of starch rich concentrates to reach the energy requirements for intensive work. Last but not least, feeding multiple small meals throughout the day is preferred over feeding a larger meal twice a day.
\end{abstract}

\section{SAMENVATTING}

Sporten in uitgevaste toestand heeft positieve effecten op het prestatievermogen van humane atleten. Bij paarden gaat trainen in gevaste toestand gepaard met een toegenomen mobilisatie van vrije vetzuren als energiebron. Er wordt verondersteld dat de hogere beschikbaarheid van vet als energiebron leidt tot een minder snelle depletie van spierglycogeen en een trager optreden van spierverzuring. Dit draagt in belangrijke mate bij tot het minder snel optreden van spiervermoeidheid. Omgekeerd zorgt de opname van een graanmaaltijd voor een uitgesproken plasma-insulinepiek en de onderdrukking van lipolyse. Gezien ruwvoer, de hoofdcomponent van het dieet van het paard, een lange passagetijd heeft doorheen de dikke darm, wordt een volledig uitgevaste status bij het paard normaal niet bereikt; dit in tegenstelling tot wat het geval is bij de mens. Het voeren van ruwvoer induceert echter geen uitgesproken plasma-insulinepiek en inhibeert daardoor geen lipolyse. Bovendien zorgt de darmflora in de dikke darm, waar het ruwvoer gefermenteerd wordt, voor een buffer van water en elektrolyten, alsook voor een continue bron van propionzuur. Dit propionzuur wordt verwerkt in de lever, waar het een precursor is voor de gluconeogenese. In tegenstelling tot wat bekend is bij menselijke atleten is er bij paarden nog heel wat te ontdekken wat betreft optimale diëtaire interventies voorafgaand aan competitie enerzijds en training anderzijds. Welke aanpak er ook gekozen wordt, ruwvoer van hoge kwaliteit hoort het sleutelingrediënt te zijn van elk paardendieet. De meeste paarden presteren even goed tot zelfs beter als ze op een dieet staan met een lager suikergehalte (dus minder of geen krachtvoer), op voorwaarde dat hoog kwalitatief ruwvoer wordt aangeboden (gras, voordroog of hooi) in combinatie met een vitaminen/ mineralensupplement. Andere alternatieven om niet-structurele koolhydraten te verlagen in het dieet van een paard met een hoge energiebehoefte is het gebruik van bijvoorbeeld vezelrijke krachtvoeders of gepilleteerde ruwvoerderbronnen, zoals luzernekorrels. Tot slot heeft het frequent voederen van meerdere kleine maaltijden per dag de voorkeur boven het voederen van twee "grote" maaltijden per dag. 


\section{INTRODUCTION}

In free nature, horses forage all day and cover on average 15 kilometres per day, mostly at a slow pace (Hampson et al., 2010). Sudden episodes of fast locomotion only occur occasionally in case the herd is alarmed by possible predator animals. Domestication has changed this natural equine lifestyle dramatically. The way horses are housed and managed nowadays, greatly differs from these natural conditions. Competition implies that highly intensive or prolonged exercise is imposed upon horses, on a regular basis, often alternated with long periods of box rest. Pasture turnout is not always an option. The contemporary equine diet often consists of a combination of roughage and (large) grain meals (Burk and Williams, 2008; Hoffman et al., 2009). It is well known that both exercise and (meal) feeding are accompanied by great fluctuations in plasma hormone levels (Freestone et al., 1991; Vervuert et al., 2009). This has triggered researchers to study the effects of performing exercise in either fed (post-prandial) or fasted state. Meal uptake triggers for example insulin release, which is a hormone, well known for its anabolic effects. When exercise is performed, substrates need to be mobilized. However, anabolic hormones tend to antagonize such mobilization. In human athletes, beneficial effects of exercising in the fasted state have been demonstrated (De Bock et al., 2005; Van Proeyen et al., 2011).

The equine and human diet are quite different. Roughage is the major component of the equine diet. Because of the long retention time of roughage in the hindgut the 'fasted' state in a horse differs from that in humans. Research in horses has shown that hormone fluctuations, i.e. insulin fluctuation that causes the postprandial 'anabolic state', are far more pronounced after uptake of grain meals than after roughage feeding (Stull and Rodiek, 1995). Therefore, the restriction of grain meals could be interpreted as a 'fasted' state in horses, despite the availability of roughage. This article aims to provide an overview of the available equine and human literature regarding training in fasted status versus training after grain meal feeding, keeping in mind the specific features of the equine gastrointestinal tract.

Both intensity and type of exercise determine which fuels are being mobilized to generate ATP for muscle contraction

Several different fuels can be used by the muscle cells to produce adenosine-tri-phosphate (ATP), which is the ultimate fuel for muscle contraction. All these fuels, such as creatine phosphate, glycogen and fat, are not mobilized and used at the same time during exercise. There is a sequential pattern, which is called energy partition. The pattern of this energy partition depends on the intensity and duration of the performed exercise. The energy partition, and thus the sequence, in which fuels are being mobilized for the ultimate ATP production, will greatly differ between medium grade long term intensity exercise (endurance), versus high intensity short duration (explosive) exercise. In general, when the muscle starts to work, it first consumes all ATP that is present within the muscle cell. This only provides enough energy for the muscle cell to cover exercise performance during fractions of seconds. Subsequently, intracellular stored creatine phosphate is used to rephosphorylate adenosine-di-phosphate (ADP) to ATP. The advantage of this fuel is that it can generate ATP very quickly. The process is anaerobic, without production of lactic acid. However, creatine phosphate storages are limited in the muscle cell and can only provide energy for a few seconds. Certain types of training approaches can enhance the creatine phosphate pathway. This is called creatine phosphate pooling training and is applied in human sports disciplines, in which a lot of accelerations and decelerations occur, such as tennis, football and skating. After creatine phosphate stores are depleted, anaerobic glycolysis starts up. Glycogen is used in absence of oxygen, which allows for rapid production of ATP. However, the process is quite inefficient. It rapidly uses up muscle glycogen stores. Moreover, lactic acid is produced as waste product. The generated lactic acid can be processed back to glucose in the liver by means of the Cory cycle. Thereafter, the newly generated glucose diffuses back from the hepatocytes into the bloodstream, from which it can be taken up again as energy source by the exercising muscles. However, this cycle is quite inefficient and shouldn't be viewed as a major energy provider for the exercising muscle.

Depending on the type, intensity and duration of the performed exercise, but also depending on the muscle type and the level of training, three to four minutes after the start-up of exercise, the aerobic glycolysis kicks in. Carbohydrates are burned in the presence of oxygen and generate large amounts of ATP in a very efficient way. For each mole of glucose, 36 moles of ATP are generated. For comparison: anaerobic glycolysis generates two to three moles of ATP out of one mole of glucose. Finally, thirty minutes after the start-up of exercise, aerobic lipolysis is launched, at least in humans. Although it consumes large amounts of oxygen, it is quite an efficient way to generate ATP (MacLeay, 2010; Vervuert, 2011).

Thus, after muscular creatine phosphate is depleted, the muscle needs either glucose or non-esterified fatty acids (NEFA) in order to synthesize ATP through respectively glycolysis (either anaerobic or aerobic) or fat-oxidation (always aerobic).

Within the muscle cell, glucose is stored as glycogen. Glycogen is a carbohydrate, which consists of multiple glucose monomers. Fats are stored as triglycerides within the muscle cells (Pösö et al., 2008). 
Non-structural carbohydrates, which are well represented in grain meals, and short-chain fatty acids, which are produced by the cecal and colonic microflo$\mathrm{ra}$, are absorbed at the level of the gastrointestinal tract and transported by means of the portal circulation to the liver. Propionic acid is an important short-chain fatty acid. It is thought to contribute for up to $60 \%$ of the plasma glucose in horses fed a hay diet (Simmons and Ford, 1991). Acetic acid is quantitatively the most important VFA in the horse. The liver plays a pivotal role in the energy metabolism. The liver can release glucose into the blood stream by either glycogenolysis, which entails the breakdown of liver glycogen stores, or gluconeogenesis (Dashty, 2013). Gluconeogenesis occurs in hepatocytes and entails that the liver converts substances, such as amino acids, glycerol, lactic and propionic acid into glucose, which is on its turn released into the blood stream and transported to the muscle cells (Lacombe et al., 2006; Rui, 2014). However, this process is very inefficient with respect to the required energy. A special form of hepatic gluconeogenesis is the Cori cycle, during which lactic acid is retrieved from the blood stream and converted into glucose. It is an important way of the body to cope with increased blood lactic acid levels during exercise (Dashty, 2013).

The hydrophilic glucose molecules can pass the phospholipid bilayer of the muscle cell membrane by means of transmembranous glucose transporters (GLUTs). Equine muscle cells and adipose tissue contain the insulin-dependent GLUT4 transporters to realize glucose uptake and to prevent hyperglycemia (van Dam et al., 2004; Manso Filho et al., 2007).

The buildup of fat depots occurs when adipose tissue takes up either plasma glucose or NEFAs. This process of lipogenesis is strongly supported by the anabolic hormone insulin. The opposite occurs during exercise, when lipolysis releases glycerol and NEFA (the building blocks of triglycerides) into the blood stream (Lacombe et al., 2006; Rui, 2014). NEFA are used as an energy source in muscle and other tissues through beta-oxidation. This requires transport of NEFA from the cytoplasm of the cell into the mitochondria by the carnitine shuttle (Houten and Wanders, 2010; Saponaro et al., 2015).

In human athletes, there is much more known about the essentials of pre-exercise feeding than in horses, both with respect to which type of nutrients need to be provided versus avoided, as with respect to timing. In human sports medicine, there is an increasing load of evidence that the time point, at which certain changes in the diet are introduced, are as important as the applied change itself. In horses, knowledge concerning this subject is still very limited. Evidently, pre-exercise feeding management of the Thoroughbred or Standardbred racehorse differ from that of an endurance horse. With respect to competition, in general, two time points are viewed as strategically essential, namely 24 to 48 hours before competition and the six- to eight-hour period before competition. Pre-competition feeding aims for supporting optimal performance capacity. The feeding approach that is applied throughout training aims for enhancing training effects. As mentioned previously, meal feeding influences the hormonal household, so does exercise. Optimal feeding management aims to combine these effects in the most optimal way, keeping the circumstances in mind: training versus competition.

Hormonal household after meal feeding and during exercise

After meal uptake, anabolic hormone profiles are dominant, amongst which insulin is the most important. The main goal is to store the energy of the meal inside the body. The opposite occurs during exercise, when high levels of catabolic hormones enable mobilization of energy stores. The most important catabolic hormones that are released during exercise are glucagon, adrenaline and cortisol.

Insulin

Insulin is produced by the $\beta$-cells in the islets of Langerhans of the pancreas in answer to increasing plasma glucose levels that occur after meal uptake. In horses, plasma insulin peaks approximately two hours after meal uptake, and the height of the insulin peak depends on the glycemic index of the feed $(\mathrm{Pa}-$ gan and Harris, 1999; Vervuert et al., 2009; Rutter et al., 2015). Insulin promotes the storage of substrates and thus leads to decreased plasma glucose and NEFA levels (Dimitriadis et al., 2011). Catecholamines inhibit insulin secretion at the level of the pancreatic islets, and cortisol induces insulin resistance in the peripheral tissues (Andrews and Walker, 1999; Hellman et al., 2014).

Insulin enhances glycogenogenesis and inhibits gluconeogenesis (Dimitriadis et al., 2011; Rui, 2014). At the level of the hepatocyte, it leads to internalization of the apically expressed glucose transporter 2 (GLUT2) and thus a decrease in hepatic glucose efflux to the bloodstream (de Graaf-Roelfsema, 2014). At the level of the muscle cell, insulin stimulates glucose uptake by increased expression of GLUT 4 transporters, at least in humans (Dimitriadis et al., 2011). There is no consensus in the literature about the relevance of insulin-mediated GLUT4-translocation in equine muscle cells, because this translocation might already be close to its maximum under basal conditions (Waller et al., 2011; de Graaf-Roelfsema, 2014).

Insulin promotes glucose and triglyceride uptake from the blood stream by fat tissue, and thus promotes lipogenesis. In muscle cells, the oxidation of fat is suppressed by insulin through the inhibition of beta-oxidation and the carnitine shuttle (Dimitriadis et al., 2011). 


\section{Glucagon}

The $\alpha$-cells of the islets of Langerhans secrete glucagon when plasma glucose is low (Gylfe et al., 2014). Catecholamines increase glucose levels inducing a hyperglycemic effect. This is achieved directly through stimulation of glycogenolysis and gluconeogenesis in the liver and indirectly through the enhancement of glucagon secretion by the pancreas. (Rorsman et al., 2014). In contrast to hepatocytes and adipose tissue, muscle cells do not express glucagon receptors (Jiang and Zhang, 2003). Therefore, glucagon has a direct effect on the liver and adipose tissue in order to increase substrate availability for all tissues, including the muscles that are not directly affected by glucagon.

Glucagon stimulates lipolysis, the carnitine shuttle and beta-oxidation and inhibits lipogenesis. The resulting increase in lipolysis leads to higher plasma NEFA levels (Rui, 2014; Sandoval and D'Alessio, 2015).

\section{Catecholamines}

Adrenaline is produced in the adrenal medulla in response to exercise and has a role in the carbohydrate and lipid metabolism. The amount of adrenaline secretion is positively correlated with the intensity of exercise (Currie et al., 2012; Guérineau et al., 2012).

The binding of epinephrine on the $\beta 2$-receptor promotes glycogenolysis and gluconeogenesis, which causes a rise in plasma glucose (Barth et al., 2007). The stimulation of the $\beta 3$-receptor at the level of adipose tissue leads to increased lipolysis and thus increased plasma NEFA levels (Frühbeck et al., 2014; Rui et al., 2014).

\section{Cortisol}

Exercise provokes a rise in plasma cortisol produced by the adrenal cortex (Raff et al., 2014). Cortisol stimulates the hepatic glucose efflux and thus increases plasma glucose by enhancing gluconeogenesis and glucose-6-phosphatase production (Kyrou et al., 2006). Furthermore, cortisol has a catabolic effect on protein metabolism and thus increases the substrate availability for gluconeogenesis. On the other hand, GLUT4 is decreased because of cortisol and this inhibits the glucose uptake by muscle cells (Powers and Howley, 2009).

In the exercising horse, cortisol stimulates lipolysis and thus increases plasma NEFA levels (Kyrou et al., 2006).

\section{Hormonal household in the fasted state versus the postprandial state}

Exercising the horse triggers the secretion of catecholamines, cortisol and glucagon. This results in an increase in glycogenolysis, gluconeogenesis, lipolysis and beta-oxidation (see above). The exact regulation of glucose transporters in the horse is not clarified yet, but GLUT4 (and possibly GLUT8 and GLUT12) could be upregulated because of exercise, leading to a higher glucose influx in muscle cells (de Graaf-Roelfsema, 2014; Lacombe, 2014). In horses, insulin-mediated GLUT translocation is limited when compared to humans. This entails that horses rely to a much lesser extend upon meal feeding induced plasma glucose peaks to restore muscle glycogen reserves. It probably also explains why it takes horses much longer to restore depleted glycogen reserves (up to three days) than humans (Lacombe et al., 2006).

Digestion, as opposed to exercise, leads to an insulin peak and thus an 'anabolic' state, in which substrate (carbohydrates, lipids) availability in the plasma is lowered. Additionally, insulin inhibits the carnitine shuttle in the muscle, which further decreases the use of lipids as energy source. These effects of insulin might have a negative impact on postprandial exercise performance capacity. Grain meals have a high glycemic index, causing a glucose peak and associated insulin peak about two hours post-feeding (Pagan and Harris, 1999). Because of the lower glycemic index of roughage, roughage does not induce such explicit insulin peaks (Stull and Rodiek, 1995). Therefore, roughage feeding largely avoids occurrence of these postprandial effects. The long gastrointestinal tract of the horse implies that there is always (and should always be) some roughage present, even in the 'fasted' state.

In fasted horses, the plasma glucose level is stable during rest on short term. It rises quickly after the onset of exercise because of hepatic glycogenolysis and gluconeogenesis. A pre-exercise meal (grain or roughage) and the associated insulin response lead to a lower hepatic glucose efflux, which has been demonstrated by Lawrence et al. (1993) as they could not observe a decrease in hepatic glycogen during postprandial exercise, in contrast to exercise in the fasted state. Therefore, a drop in plasma glucose is seen at the onset of postprandial exercise in horses despite the carbohydrate reserve present in the gastrointestinal tract (Jose-Cunilleras et al., 2002). A negative impact on performance capacity at the start of exercise may occur, although, this is doubted by Jeukendrup and Killer (2010). The gradual rise in plasma glucose level during exercise is less pronounced in postprandial horses than in fasted horses. However, this is not seen during short, heavy exercise bouts (Lawrence et al., 1993; Lawrence et al., 1995; Jose-Cunilleras et al., 2002).

Despite the lower plasma glucose, a higher turnover of glucose is seen, which is due to the higher gastrointestinal uptake and higher use of glucose as energy source during exercise in the postprandial state (Geor et al., 2000a; Jose-Cunilleras et al., 2002). Ad libitum roughage uptake isn't associated with the manifestation of important plasma insulin peaks (Stull and 
Rodiek, 1995). Moreover, roughage is thought to promote hepatic gluconeogenesis because it supplies the liver with propionic acid and thus enables the horse to keep plasma glucose stable for a long time (Brunner et al., 2015).

Plasma NEFA concentrations gradually rise over time in the fasted horse during rest and decrease after feeding. At the onset of exercise, a sharp decline in NEFA is seen in the fasted horse (Pagan and Harris, 1999; Jose-Cunilleras et al., 2002). During exercise, NEFA levels gradually rise in both fasted and postprandial horses. During high-intensity exercise however, a decline in plasma NEFA is seen. NEFA levels remain at all times higher in the fasted horse than in postprandial exercising horses (Lawrence et al., 1995; Jose-Cunilleras et al., 2002). These differences in plasma NEFA kinetics indicate that both beta-oxidation and lipolysis are inhibited in the postprandial (grain-fed) horse and therefore, lipids can't equally contribute as energy source in these horses when compared to fasted or 'roughage only'-fed horses (Pagan and Harris, 1999).

The fasted versus the postprandial state: focus on muscle fatigue

\section{Muscle glycogen}

The horse benefits from rich muscle glycogen stores. Depletion of muscle glycogen during exercise leads to muscle fatigue and is of great importance as a limiting factor for performance of long-duration/ low-intensity exercise. In that type of exercise, muscle acidification is less of a concern. Therefore, muscle glycogen concentration at the onset of exercise is very important to postpone fatigue (Pösö et al., 2008). Interestingly, muscle glycogen consumption is similar to or more pronounced during postprandial exercise than during exercise in the fasted state (Lawrence et al., 1993; Lawrence et al., 1995; Geor et al., 2000a). A higher glycogen consumption could be explained by an insulin-mediated lower NEFA availability in the postprandial horse (Brunner et al., 2015). Replenishment of glycogen after complete depletion takes approximately 72 hours in the horse; this in contrast to the human athlete, where this replenishment is completed within 24 hours (Lacombe et al., 2006; Waller and Lindinger, 2010).

'Carbohydrate loading', which is a commonly applied approach to increase muscle glycogen storages in human athletes by the uptake of sugar/starch-rich meals throughout the days before competition is not feasible in the horse because 1. there are serious health risks associated with feeding high starch/sugar diets to horses, such as fatal colic and laminitis 2 . synthesis of glycogen in the equine muscle is slow (72 hours) and 3. the limited insulin-mediated GLUT translocation (see above) that prevents the muscle from benefiting from glucose peaks to restore glycogen reserves, in contrast to what has been observed in humans (Lacombe et al., 2006; Waller and Lindinger, 2010; Lacombe, 2014; de Graaf-Roelfsema, 2014). On the other hand, feeding the horse low amounts of non-structural carbohydrates during exercise, e.g. during stops in endurance competitions, provides glucose without inhibition of lipolysis because the insulin-response is suppressed by catecholamines during exercise. Therefore, this strategy has a glycogen-sparing effect and might aid in postponing muscle fatigue (Geor et al., 2000a; Robert, 2014).

Intensive daily exercise results in progressive lowering of muscle glycogen concentrations due to the slow resynthesis rate. However, after a few days of relative rest, the glycogen concentration is restored or even increased when compared with the pre-training period (Lacombe et al., 2003). Therefore, high-intensive exercise is counterproductive during the two days before competition. Such high-intensive exercise bouts most probably have a negative effect on muscle glycogen reserves, which are of key importance to enable top performance. Therefore, the day before competition, strenuous exercise needs to be avoided. In human athletes, 'tapering of exercise' in the days upfront competition is a wide-spread training management approach. However, in horses, no scientific studies are available to support such an approach.

\section{Muscle acidification}

Lactate is produced in the muscle when glycogen is used under anaerobic conditions (Dashty, 2013). Lactate accumulation leads to a decrease in muscle $\mathrm{pH}$, which on its turn inhibits phosphofructokinase-1, an important enzyme necessary for glycogen breakdown. Furthermore, it has a negative impact on the myosin-actin cross-bridge cycle. Both effects lead to muscle fatigue (Pösö et al., 2008; Roberts et al., 2014).

It is hypothesized that a high contribution of carbohydrates (plasma glucose, muscle glycogen) in the energy supply during postprandial exercise results in a higher lactate production. However, it is only during high intensity exercise that the muscle relies on anaerobic glycolysis, and thus only in this type of exercise muscle, acidification is considered the main factor contributing to the onset of fatigue (Pöso et al., 2008). Pagan and Harris (1999) observed higher lactate production during postprandial exercise. However, several other authors could not confirm this increase in plasma lactate compared to fasted horses (Lawrence et al., 1993; Stull and Rodiek, 1995; Jose-Cunilleras et al., 2002).

Apart from the acute influence of pre-exercise feeding, a more long-term effect of diet composition is also seen. A sugar/starch-rich diet seems to stimulate lactate production (Jansson and Lindberg, 2012). 

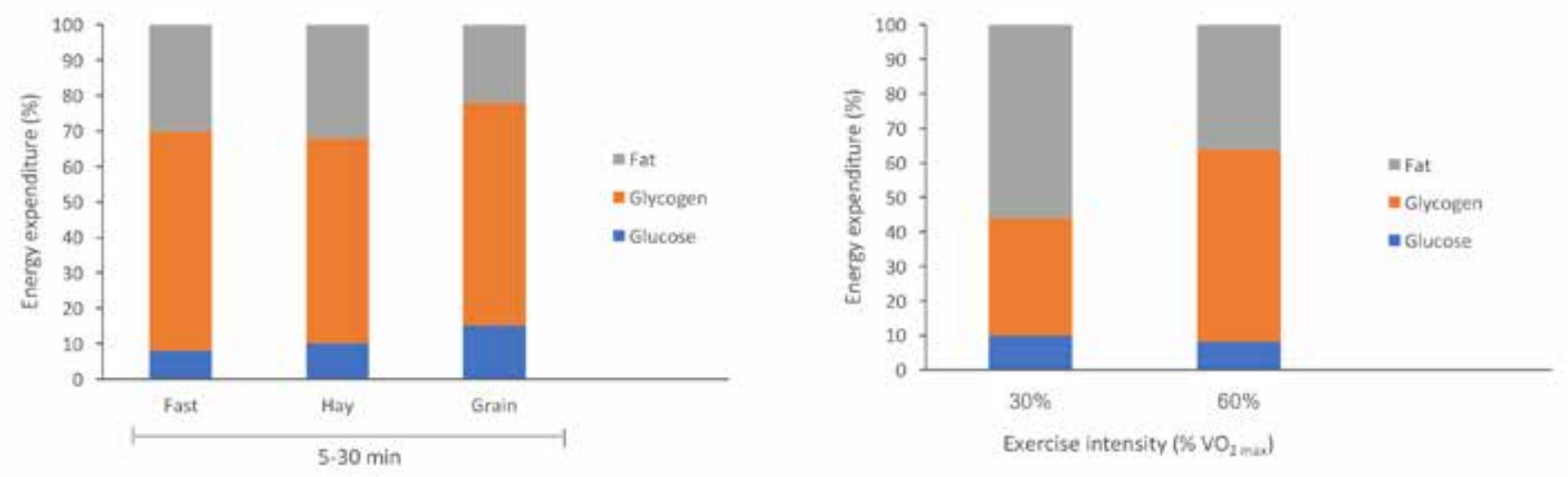

Figure 1. (Approximate) pattern of substrate utilization (from Pösö et al., 2008). Left panel: energy expenditure (\%) in function of the feeding state: the (truly) fasted, hay-fed and grain-fed horse. Grain-feeding implies that the horse needs to rely more on glucose and glycogen as energy source, whereas hay-feeding even enhances lipid oxidation through cecal- and colonic-derived, short-chain VFA. Right panel: energy expenditure in function of exercise intensity. High-intensity exercise implies a higher usage of glycogen as energy source, whereas fat oxidation is more pronounced during (prolonged) moderate-intensity exercise.

The accumulation of lactate and the onset of fatigue are delayed in horses on a roughage-only diet (Powell et al., 1999; Jansson and Lindberg, 2012).

\section{Energy partition differs when performing exercise in the fasted versus the postprandial state}

Lipid oxidation is higher in fasted horses because it is inhibited in the postprandial (grain-fed) state due to high insulin levels. Roughage feeding doesn't inhibit lipid oxidation because of its low glycemic index, and even provides short-chain VFA through cecal/ colonic fermenation (Simmons and Ford, 1991; Pagan and Harris, 1999). Grain-fed horses compensate by relying on a higher carbohydrate oxidation, which remains high during prolonged exercise, in contrast to fasted horses, in which the share of carbohydrates in energy supply declines over time in favor of fat oxidation (Geor et al., 2000a; Jose-Cunilleras et al., 2002; Pösö et al., 2008) (Figure 1).

As mentioned previously, the pattern of energy partition is defined by the duration and intensity of the performed exercise. Moderate to high-intensity exercise $\left(60 \% \mathrm{VO}_{2} \max \right)$ highly depends on glycogen as energy source, whereas during low-intensity exercise $\left(30 \% \mathrm{VO}_{2} \max \right)$, lipids are the major energy source (Geor et al., 2000b). During prolonged exercise, a shift towards lipid oxidation takes place, especially in the fasted state.

\section{DISCUSSION}

Nowadays, pre-exercise feeding management is receiving a lot of attention in human athletes. Not only the type of diet but also the time point at which dietary changes are applied, are very important. Additionally, nutritional preparation for competition differs from that during training.

In horses, the knowledge of optimal pre-competition versus pre-training feeding management is still quite limited. Feeding and training management should be strategically adapted to the sports discipline in which the horse performs, the level, at which it performs and the competition schedule.

Horses subjected to prolonged exercise of moderate intensity, such as endurance horses, rely mainly on NEFA for their energy supply (Bergero et al., 2005). The postprandial inhibition of lipolysis, which is only seen after grain meals, may therefore have a detrimental effect on their performance capacity. Horses that perform short bouts of high-intensity exercise on the contrary depend less on the lipid oxidation and might therefore be less affected by grain meals shortly before exercise. However, there is still the issue of muscle fatigue. Higher lactate production is expected to occur during postprandial exercise, although not in all studies, this suspicion could be confirmed. Therefore, exercising with ad libitum access to roughage seems to be preferred for both endurance and high-intensive work. Grain feeding should be avoided during the last few hours before exercise (Pagan and Harris, 1999). Exercise in combination with ad libitum access to roughage and no concentrate meal feeding throughout several hours prior to exercise most likely has a positive effect on thermoregulation. The plasma volume of roughage only-fed horses is more easily maintained during prolonged exercise than the one of partially grain-fed horses. The hindgut provides an enormous water and electrolyte reserve due to increased water uptake after roughage feeding and the water holding capacity of fiber (Connysson et al., 2010; Jansson and 
Lindberg, 2012). This buffer is necessary during prolonged activity, as horses may produce over $10 \mathrm{~L}$ of hypertonic sweat per hour (Larsson et al., 2013).

Ideally, endurance horses should be allowed to eat roughage (and drink) until shortly before the start of the competition (Conysson et al., 2010). In case gastrointestinal load by roughage needs to be limited, such as in racehorses, slow feeders can be the solution to provide ad libitum high-quality roughage without overconsumption. A reduction of $2 \%$ in bodyweight and associated performance benefits have been demonstrated in race horses with restricted roughage uptake ( $1 \%$ of bodyweight hay for three days) when compared to ad libitum roughage fed race horses (Rice et al., 2001). However, to avoid health and behavioral problems, a daily minimum of $1.5 \%$ BW roughage should be provided, even on competition days (Geor et al., 2008; Pagan and Harris, 1999). According to Dunnett (2013), an absolute minimum roughage intake per day is $1 \%$ of the bodyweight on dry matter basis. According to Brunner et al. (2015), the ideal timing in show jumping horses for roughage feeding is two to six hours before competition, because this timing is associated with peak NEFA and glucose availability during the timepoint of competition.

More and more authors suggest that horses can perfectly compete at high level on a roughage-only diet (Connysson et al., 2010; Jansson and Lindberg, 2012; Brunner et al., 2015). Surprisingly, this has even been demonstrated for Standardbred horses (Jansson and Lindberg, 2012). The long retention time of roughage provides a continuous source of propionic acid and thus energy through gluconeogenesis (Simmons and Ford, 1991; Jansson and Lindberg, 2012). In case a roughage-only diet is provided to competition horses, it is strongly advised to analyze the hay, so its composition is known, and to supply the horse with a vitamin and mineral mix accordingly. If hay analysis can't be performed, hay composition can be estimated based on the average composition of hay in Belgium (CVB data). When energy demands are high, fat-rich concentrates or oil supplementation can be considered, apart from the commonly used grain-based concentrates. Faster race times have been attributed to oil supplementation because of a faster depart. This might be due to higher pre-exercise muscle glycogen concentrations (Harris and Harris, 2005). For horses subjected to prolonged exercise, oil supplementation is thought to have additional beneficial effects because 1 . it further stimulates the muscular uptake and use of NEFA (Geelen et al., 1999; 2001; Dunnet et al., 2002) and 2. it could also reduce metabolic heat production (Harris and Harris, 2005; Robert, 2014). Oil supplementation might also be beneficial in sensitive horses, because it has been shown to decrease (re)activity (Holland et al., 1996). Excessive oil supplementation is associated with adverse effects such as reduced microbial activity and fiber fermentation in the large intestine (Jansen et al., 2002; 2007). This probably explains the diarrhea that might occur when promptly switching to a fat-enriched diet. Therefore, the supplementation of oil should always be increased gradually, up to a maximum of $1 \mathrm{~mL} / \mathrm{kg}$ bodyweight per day. Furthermore, with increased oil doses, vitamin $\mathrm{E}$ demands increase (anti-oxidative function) and an additional 1 to $1.5 \mathrm{IU}$ of vitamin $\mathrm{E}$ per $\mathrm{mL}$ oil is advised to prevent oxidation (Harris, 2009).

Because of the current practice of using fat as an additional energy source (either as fat-rich concentrates or simple oil supplementation), the authors want to warn that fat-rich diets were also thought to have beneficial effects on performance capacity of human athletes, somewhat a decade ago. Fat-rich diets enhance NEFA utilization and increase intracellular muscle lipid storage (Vogt et al., 2003). Despite these potential physiological benefits, no increase (and even an attenuation) of performance capacity has been seen in human athletes consuming fat-rich diets compared to sugar/starch-rich diets, probably due to a decrease in intramuscular glycogen storages (Helge, 2000; Burke et al., 2004; Erlenbusch et al., 2015). Therefore, in human athletes, the approach to only provide high-fat diets has been abandoned. Moreover, in human medicine, it is now accepted that there is no "onediet-fits-all" solution and that periodization is the key, in which high-fat and high-carbohydrate diets are alternated depending on the training cycle and competition schedule (Burke, 2015). In horses, there is still much to be learned when it comes to periodization and the effects of changing the diet in preparation to competition and as a means to enhance recuperation after competition. While exploring these possibilities, it should be kept in mind that there are several health risks associated with high non-structural carbohydrate meals, i.e. starch and/or sugar, and sudden changes in diet, such as gastric ulceration, colic and laminitis.

\section{CONCLUSION}

During exercise, fuels are used to produce energy for muscles. Depending on the intensity and duration of the exercise, different substrates are mobilized to produce energy at different time points. Normally, the muscle cells first utilize ATP storages and rephosphorylate ADP with creatine phosphate. The anaerobic glycolysis will then be engaged and only after a long exercising period, the aerobic glycolysis and lipolysis start, which are much more efficient pathways to produce energy. In human athletes and horses, it has been shown that training in fasted status has several positive effects: this way, a post-prandial insulin peak is avoided and lipolysis can thus start. In horses, the 'fasted' status corresponds to a roughage-only fed horse. Roughage must be the main ingredient of the 
horse diet and is much more important than starchrich concentrates. Roughage is not a trigger for insulin release and has several other advantages, such as the production of VFA's that are energetic molecules.

\section{REFERENCES}

Andrews R.C., Walker B.R. (1999). Glucocorticoids and insulin resistance: old hormones, new targets. Clinical Science 96, 513-523.

Barth E., Albuszies G., Baumgart K., Matejovic M., Wachter U., Vogt J., Radermacher P., Calzia E. (2007). Glucose metabolism and catecholamines. Critical Care Medicine 35, 508-518.

Bergero D., Assenza A., Caola G. (2005). Contribution to our knowledge of the physiology and metabolism of endurance horses. Livestock Production Science 92, $167-$ 176.

Brunner J., Liesegang A., Weiss S., Wichert B. (2015). Feeding practice and influence on selected blood parameters in show jumping horses competing in Switzerland. Journal of Animal Physiology and Animal Nutrition 99, 684-691.

Burk A.O., Williams C.A. (2008). Feeding management practices and supplement use in top-level event horses. Comparative Exercise Physiology 5, 85-93.

Burke L.M., Kiens B., Ivy J.L. (2004). Carbohydrates and fat for training and recovery. Journal of Sports Sciences $22,15-30$.

Burke L.M. (2015). Re-examining high-fat diets for sports performance: did we call the 'nail in the coffin' too soon? Sports Medicine 45, Supplement 1, 33-49.

Connysson M., Essén-Gustavsson B., Lindberg J.E., Jansson A. (2010). Effects of feed deprivation on Standardbred horses fed a roughage-only diet and a 50:50 forage-oats diet. Equine Veterinary Journal 42, 335-340.

Currie G., Freel E.M., Perry C.G., Dominiczak A.F. (2012). Disorders of blood pressure regulation: role of catecholamine biosynthesis, release, and metabolism. Current Hypertension Reports 14, 38-45.

Dashty M. (2013). A quick look at biochemistry: Carbohydrate metabolism. Clinical Biochemistry 46, 1339-1352.

De Bock K., Richter E.A., Russel A.P., Eijnde B.O., Derave W., Ramaekers M., Koninckx E., Léger B., Verhaeghe J., Hespel P. (2005). Exercise in the fasted state facilitates fibre type-specific intramyocellular lipid breakdown and stimulates glycogen resynthesis in humans. Journal of Physiology 564, 649-660.

de Graaf-Roelfsema E. (2014). Glucose homeostasis and the enteroinsular axis in the horse: a possible role in equine metabolic syndrome. The Veterinary Journal 199, 11-18.

Dimitriadis G., Mitroub P., Lambadiari V., Maratoub E., Sotirios A.R. (2011). Insulin effects in muscle and adipose tissue. Diabetes Research and Clinical Practice 93, 52-59.

Dunnett C.E., Marlin D.J., Harris R.C. (2002). Effect of dietary lipid on response to exercise: relationship to metabolic adaptation. Equine Veterinary Journal 34, 75-80.

Dunnett C.E. (2013). Ration evaluation and formulation. In: Geor R.J., Coenen M., Harris P. (editors). Equine Applied and Clinical Nutrition. Elsevier, Edinburgh, p. 405-424.
Erlenbusch M., Haub M., Munoz K., MacConnie S., Stillwell B. (2005). Effect of high-fat or high-carbohydrate diets on endurance exercise: A Meta-Analysis. International Journal of Sport Nutrition and Exercise Metabolism 15, 1-14.

Freestone J. F., Wolfsheimer K. J., Kamerling S. G., Church G., Hamra J., Bagwell C. (1991). Exercise induced hormonal and metabolic changes in Thoroughbred horses: effects of conditioning and acepromazine. Equine Veterinary Journal 23, 219-223.

Frühbeck G., Méndez-Giménez L., Fernández-Formoso J.A., Fernández S., Rodríguez A. (2014). Regulation of adipocyte lipolysis. Nutrition Research Reviews 27, 63-93.

Geelen, S.N., Sloet Oldruitenborgh-Oosterbaan M.M., Beynen A.C. (1999). Dietary fat supplementation and equine plasma lipid metabolism. Equine Veterinary Journal 31 475-478.

Geelen S. N., Blázquez C., Geelen M. J., van Oldruitenborgh-Oosterbaan M. M. S., Beynen, A. C. (2001). High fat intake lowers hepatic fatty acid synthesis and raises fatty acid oxidation in aerobic muscle in Shetland ponies. British Journal of Nutrition 86, 31-36.

Geor R.J., Hinchcliff K.W., McCutcheon L.J., Sams R.A. (2000a). Epinephrine inhibits exogenous glucose utilization in exercising horses. Journal of Applied Physiology 88, 1777-1790.

Geor R.J., Hinchcliff K.W., Sams R.A. (2000b). Beta-adrenergic blockade augments glucose utilization in horses during graded exercise. Journal of Applied Physiology 89, 1086-1098.

Geor R.J. (2008). Nutritional management of the equine athlete. In: Hinchcliff K., Kaneps A.J., Geor R.J. (editors). Equine Exercise Physiology. Elsevier, Edinburgh, p. 301-325.

Guérineau N.C., Desarménien M.G., Carabelli V., Carbone E. (2012). Functional chromaffin cell plasticity in respons to stress: Focus on nicotinic, gap junction, and voltage-gated Ca2+ channels. Journal of Molecular Neuroscience 48, 368-386.

Gylfe E., Gilon P., (2014) Glucose regulation of glucagon secretion. Diabetes Research and Clinical Practice 103, $1-10$.

Hampson B.A., De Laat M.A., Mills P.C., Pollit C.C. (2010). Distances travelled by feral horses in 'outback' Australia. Equine Veterinary Journal 42, Supplement 38, 582-586.

Harris P.A., Harris R.C. (2005). Ergogenic potential of nutritional strategies and substances in the horse. Livestock Production Science 92, 147-165.

Harris P.A. (2009). Feeding management of elite endurance horses. Veterinary Clinics of North America: Equine Practice 25, 137-153.

Helge J.W. (2000). Adaptation to a fat-rich diet - effects on endurance performance in humans. Sports Medicine 30, 347-357.

Hellman B., Dansk H., Grapengiesser E. (2014). Activation of alpha adrenergic and muscarinic receptors modifies early glucose suppression of cytoplasmic $\mathrm{Ca} 2+$ in pancreatic b-cells. Biochemical and Biophysical Research Communications 445, 629-632.

Hoffman C.J., Costa L.R., Freeman L.M. (2009). Survey of feeding practices, supplement use and knowledge of equine nutrition among a subpopulation of horse owners in New England. Journal of Equine Veterinary Science 29, 719-726. 
Holland, J.L., Kronfeld, D.S., Meacham, T.N. (1996). Behavior of horses is affected by soy lecithin and corn oil in the diet. Journal of Animal Science 74, 1252-1255.

Houten S.M., Wanders R.J.A. (2010). A general introduction to the biochemistry of mitochondrial fatty acid $\beta$-oxidation. Journal of Inherited Metabolic Disease 33, 469-477.

Jansen W.L., Geelen S.N., van der Kuilen J., Beynen A.C. (2002). Dietary soyabean oil depresses the apparent digestibility of fibre in trotters when substituted for an iso-energetic amount of corn starch or glucose. Equine Veterinary Journal 34, 302-305.

Jansen W.L., Cone J.W., Geelen S.N., Sloet van Oldruitenborgh-Oosterbaan M.M., van Gelder A.H., Oude Elferink S.J., Beynen A.C. (2007). High fat intake by ponies reduces both apparent digestibility of dietary cellulose and cellulose fermentation by faeces and isolated caecal and colonic contents. Animal Feed Science and Technology 133, 298-308. doi:10.1016/j.anifeedsci.2006.05.002. AGR:IND43876347.

Jansson A., Lindberg J.E. (2012). A forage-only diet alters the metabolic response of horses in training. Animal 6, 1939-1946.

Jiang G., Zhang B. B. (2003). Glucagon and regulation of glucose metabolism. American Journal of Physiology-Endocrinology and Metabolism 284, E671-E678.

Jeukendrup A.E., Killer S.C. (2010). The myths surrounding pre-exercise carbohydrate feeding. Annals of Nutrition and Metabolism 57, 18-25.

Jose-Cunilleras E., Hinchcliff K.W., Sams R.A., Devor S.T., Linderman J.K. (2002). Glycemic index of a meal fed before exercise alters substrate use and glucose flux in exercising horses. Journal of Applied Physiology 92, 117-128.

Kyrou I., Chrousos G.P., Tsigos C. (2006). Stress, visceral obesity, and metabolic complications. Annals of the New York Academy of Sciences 1083, 77-110.

Lacombe V.A., Hinchcliff K.W., Taylor L.E. (2003). Interactions of substrate availability, exercise performance and nutrition with muscle glycogen metabolism in horses. Journal of the American Veterinary Association 223, 1576-1585.

Lacombe V.A., Hinchcliff K.W., Kohn C.W., Reed S.M., Taylor L.E. (2006). Effects of dietary glycaemic respons after exercise on blood concentrations of substrates used indirectly for muscle glycogenesis. Equine Veterinary Journal 36, 585-589.

Lacombe V.A. (2014). Expression and regulation of facilitative glucose transporters in equine insulin-sensitive tissue: from physiology to pathology. ISNR Veterinary Science 2014, 1-15.

Larsson J., Pilborg P.H., Johansen M., Christophersen M.T., Holte A., Roepstorff L., Olsen L.H., Harrison A.P. (2013). Physiological parameters of endurance horses precompared to post-race, correlated with performance: a two race study from scandinavia. ISRN Veterinary $S c i$ ence 2013, 684353.

Lawrence L., Soderholm L.V., Roberts A., Williams J., Hintz H. (1993). Feeding status affects glucose metabolism in exercising horses. Journal of Nutrition 12, 2152-2157.

Lawrence L., Hintz H., Soderholm L.V., Williams J., Roberts A. (1995). Effect of time of feeding on metabolic response to exercise. Equine Veterinary Journal 18, 392-395.

MacLeay J.M. (2010). Disorders of the musculoskeletal system. In: Reed S.M., Bayly W.M., Sellon D.C. (editors). Equine Internal Medicine. Third edition, Elsevier, Edinburgh, p. 490.

Manso Filho H.C., McKeever K.H., Gordon M.E., Costa H.E.C., Watford M. (2007). Novel findings regarding Glut-4 expression in adipose tissue and muscle in horses-A preliminary report. The Veterinary Journal 174, 565-569.

Pagan J.D., Harris P.A. (1999). The effects of timing and amount of forage and grain on exercise response in thoroughbred horses. Equine Veterinary Journal 30, 451-457.

Pösö A.R., Hyyppä S., Geor R.J., McKeever K.G., Gordon M.E. (2008). Metabolism and nutrition. In: Hinchcliff K., Kaneps A.J., Geor R.J. (editors). Equine Exercise Physiology. Elsevier, Edinburgh, p. 248-273.

Powell D., Lawrence L.M., Brewster-Barnes T., Warren L.K., Rokuroda S., Parker A., Crum A. (1999). The effect of diet composition and feeding state on the response to exercise in feed-restricted horses. Equine Veterinary Journal 30, 514-518.

Powers S.K., Howley E.T. (2009). Hormonal responses to exercise. In: Exercise Physiology. Theory and Application to Fitness and Performance. Seventh edition, McGraw-Hill companies, New York, p. 72-105.

Raff H., Sharma S.T., Nieman L.K. (2014). Physiological basis for the etiology, diagnosis and treatment of adrenal disorders: Cushing's syndrome, adrenal insufficiency and congenital adrenal hyperplasia. Comprehensive Physiology 4, 739-769.

Rice O., Geor R., Harris P., Hoekstra K., Gardner S., Pagan J. (2001). Effects of restricted hay intake on body weight and metabolic responses to high-intensity exercise in Thoroughbred horses. 17th Conference of the Equine Nutrition and Physiology Society 2001, 273-279.

Robert C. (2014). Veterinary aspects of training and racing endurance horses. In: Hinchcliff K.W., Kaneps A.J., Geor R.J. (editors). Equine Sports Medicine and Surgery. Second edition, Elsevier, Edinburgh, p. 1083-1106.

Roberts C., Harris P., Murray R., Cnockaert R. (2014). The relationship between blood lactate, serum muscle enzymes, jumping performance and muscle soreness in show-jumping horses. International Conference on Equine Exercise Physiology 46, 9.

Rorsman P., Ramracheya R., Rorsman N.J.G., Zhang Q. (2014). ATP-regulated potassium channels and voltagegated calcium channels in pancreatic alpha and beta cells: similar functions but reciprocal effects on secretion. Diabetologia 57, 1749-1761.

Rui L. (2014). Energy metabolism in the liver. Comprehensive Physiology 4, 177-197.

Rutter G.A., Pullen T.J., Hodson D.J., Martinez-Sanchez A. (2015). Pancreatic $\beta$-cell identity, glucose sensing and the control of insulin secretion. Biochemical Journal 466, 203-218.

Sandoval D.A., D’Alessio D.A. (2015). Physiology of proglucagon peptides: role of glucagon and glp-1 in health and disease. Physiological Reviews 95, 513-548.

Saponaro C., Gaggini M., Carli F., Gastaldelli A. (2015). The subtle balance between lipolysis and lipogenesis: A critical point in metabolic homeostasis. Nutrients 7, 9453-9474.

Simmons H.A., Ford E.J. (1991). Gluconeogenesis from propionate produced in the colon of the horse. British Veterinary Journal 147, 340-345. 
Stull C., Rodiek A. (1995). Effects of postprandial interval and feed type on substrate availability during exercise. Equine Veterinary Journal 18, 362-366.

van Dam K. G., van Breda E., Schaart G., van Ginneken M. M., Wijnberg I. D., de Graaf-Roelfsema E., van der Kolk J.H., Keize, H. A. (2004). Investigation of the expression and localization of glucose transporter 4 and fatty acid translocase/CD36 in equine skeletal muscle. American Journal of Veterinary Research 65, 951-956.

Van Proeyen K., Szlufcik K., Nielens H., Ramaekers M., Hespel P. (2011). Journal of Applied Physiology 110, 236-245.

Vervuert I., Voigt K., Hollands T., Cuddeford D., Coenen M. (2009). Effect of feeding increasing quantities of starch on glycaemic and insulinaemic responses in healthy horses. The Veterinary Journal 182, 67-72.

Vervuert I. (2011). Energy metabolism of the performance horse. In: Proceedings of the 5th European Equine Nutrition \& Health Congress. Waregem, p. 23-34.
Vogt M., Puntschart A., Howaldi H., Mueller B., Mannhart C., Gfeller-Tuescher L., Mullis P, Hoppeler H. (2003). Effects of dietary fat on muscle substrates, metabolism, and performance in athletes. Medicine \& Science in Sports \& Exercise 35, 952-960.

Waller A.P., Lindinger M.I. (2010). Nutritional aspects of post exercise skeletal muscle glucogen synthesis in horses: a comparative review. Equine Veterinary Journal 42, 274-281.

Waller A. P., Burns T. A., Mudge M. C., Belknap J. K., Lacombe V. A. (2011). Insulin resistance selectively alters cell surface glucose transporters but not their total protein expression in equine skeletal muscle. Journal of Veterinary Internal Medicine 25, 315-321.

\section{verschillende anesthesie configuraties}

\section{foto's : zie website}

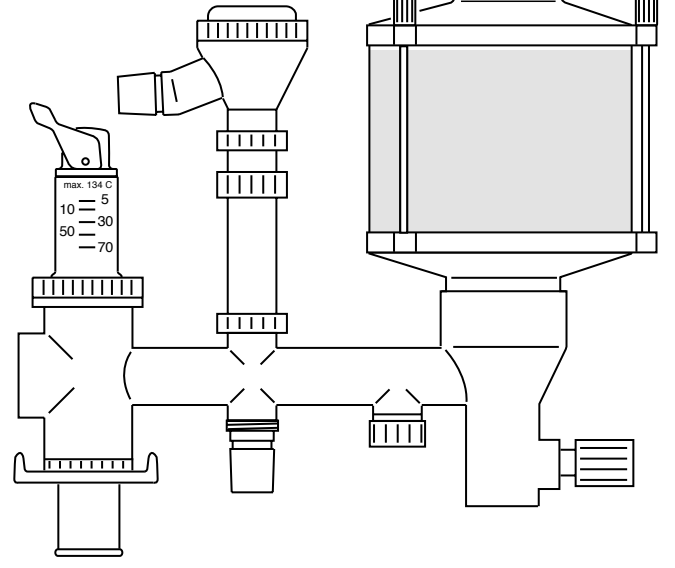

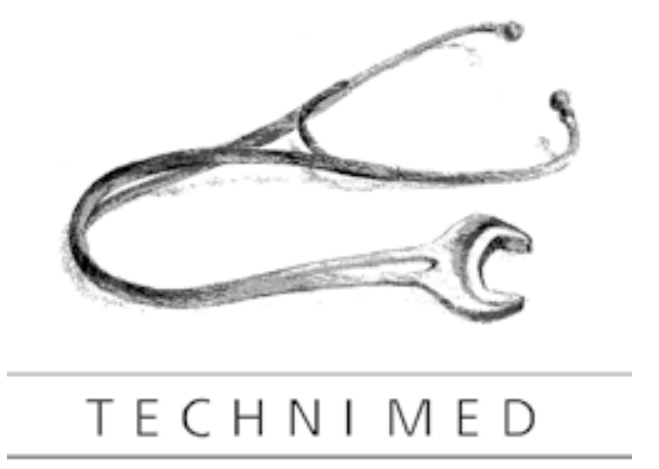

Tweedehands Anesthesietoestellen (specialist Dräger) met Zuurstofgenerator (tweedehands) www.technimed.be 